\title{
Are the Social Sciences Really- and Merely- Sciences?
}

\author{
Jeffrey Foss \\ University of Victoria \\ Canada
}

\section{Introduction}

Are the social sciences (psychology, political science, economics, anthropology, sociology, etc.), really sciences? I will argue that the answer is yes, they really are sciences - but not merely sciences. The defining subject of the social sciences, the human being, makes them sciences of a special sort, for the human being is an insoluble mystery with inviolable rights. On one hand this denies social science complete knowledge of its subject, the human being, and on the other gives it responsibilities for humankind.

One philosophically deep truth - the real lowdown, as they say - is that the human being, viewed as a physical system, is chaotic (Foss 1992). This means that physics as such cannot predict the behavior of the human being as a physical system, even if its onboard computer, the brain, is included-or we should say because the brain is included, for that beguiling chunk of biological information processing matter between our ears makes us an essentially open system. As it turns out, we are informavores (Miller 1983, Dennett 1996) of considerable sophistication, with deeply imbedded social systems that satisfy our craving for knowledge and belief - however well or poorly informed. Our hunter-gatherer ancestors hunted information with their eyes and gathered it with their ears. With the printing press we learned to consume books, and nowadays we graze on the internet.

Because we are informavores, science (whether physical or social) has to cooperate (or compete) with the humanities to explain the behavior of the human being-and this has enormous implications for the ethics of the social sciences, and in particular its interpretation of scientific objectivity. Light travelling from a distant star, to take just one example from infinitely many, is just light from a physical point of view. Because we can see it, we can extract information from it, and so it carries information for us-even though the light may have been emitted by the star before our species even existed. Physical science cannot specify the information carried by the light, but only its physical parameters, its wavelength, frequency, energy, momentum, speed, etc. Even more striking is the fact that there is no way to define or specify the information it carries - the meaning of the light - for that varies with the perceiver. The child sees only a point of light, whereas the adult sees a star, and the astrophysicist sees a red giant on the point of exploding, and so on.

What anything means depends on what the perceiver can take from it-and that could be anything. For example, the meaning of light from a star for a soldier in a trench may be this: the sky is clearing, so we will be attacking. In other words, the meaning of anything depends on 
how it's interpreted, and there are always infinitely many possible interpretations. So, because we are informavores, physical science cannot understand us, for meaning and interpretation are not within its scope, but lie within the domain of human interests and feelings - the domain, traditionally, of the humanities (literature, history, philosophy, languages, drama, art, etc.). Because Homo sapiens employs meaning in most aspects of its behavior, the social sciences lie athwart the boundary between the humanities and the physical sciences. (Foss 2007, 2011).

\section{The myth of Smith}

To explain, please let me, a humanist, employ a myth, in the same spirit as my intellectual forefather, Plato, employed myths: to glimpse wisdom. Picture a group of soldiers marshaled on a ship deck in the cold grey dawn of a day in November, 1940. They struggle to keep their balance as the officer on the bridge warns them that in two minutes they will hear the siren calling them to their battle stations. They are soldiers, therefore cargo, so their battle station was below decks. The siren blares, startling one soldier, who jerks to attention. His petty officer taps him on the soldier and says, "Private Smith, uh, I regret to inform you, uh, private, that wireless has just informed us that, uh..., well, your mother has died."

Consider now two possible outcomes: in outcome ${ }_{1}$, our system, Private John Smith, an airframe mechanic, follows a course of events that results in his becoming, by May of 1944, a Nazi spy - whereas in outcome 2 , Smith becomes a British spy.

Here, the philosophically deep truth is that the social scientist has little more to tell us which course of action will be taken by Smith than does the humanist-as proven by the physical sciences. Physical science tells us that there is no way to predict which of the two observable outcomes will take place in 1944, because at that cold grey dawn in 1940 they both had a probability of zero. They were just two among an uncountable infinity of possibilities, so the probability of any of them is one divided by infinity, which is zero. Non-mathematicians may picture the uncountable infinity of points in any given circle: the probability that a mathematical point tossed at the circle will hit a specified point in the circle (given the nondenumerable infinity of points in any direction, however small, from the given point) is zero. And so, yes, things of zero probability - which is, after all, just a human measure of what to expect-do happen. In fact, they happen all the time. But they are therefore unpredictable.

B. F. Skinner once quipped, "You can't have a science about a subject matter which hops capriciously about" (Skinner 1948, p. 76). One goal of this paper is to help us understand how, contrary to Skinner, you can have a science about unpredictable phenomena, including the human phenomenon. Just before the passage quoted above, Skinner's protagonist says "I deny that freedom exists at all. I must deny it-or my program would be absurd." So we must also understand how freedom may exist-despite some scientists' attempt to abolish it in order to justify and motivate their science. Fortunately, freedom and science can happily coexist, as we shall see.

\section{The role of physics in science and society}

Ah yes, the physical sciences! The social sciences are defined, whether they like it or not, by their contrast with the physical sciences. ${ }^{1}$ The paradigm of the physical sciences is physics.

\footnotetext{
${ }^{1}$ It is usual for the physical sciences, physics and chemistry along with their sub-disciplines such astrophysics and biochemistry, to be misleadingly nominated "the natural_sciences" (even, or especially,
} 
Physics defines the ontology of the other natural sciences, the fundamental particles and forces of which everything is made, their causal connections, even space and time themselves. Physics is unified and complete, exhaustively spanning its domain with precision and accuracy. Physics unlocks the mysteries of chemistry, tracks the past through isotope dating, unravels the DNA control codes at the heart of each cell, and reveals the firings of our neurons as we ponder it all.

To the extent that knowledge is power, physical science represents this power-and all its consequent authority-to our species. Physical science gave us the atomic bomb, the transistor, the information age, and social networking. It has transfigured the globe and Homo sapiens. For the many (to coin Aristotle's useful term), science is identified with physics, and so for them the answer to our question is clear: since knowledge is power, the social sciences are not sciences, or at least are not successful sciences. This view, although quite reasonable given its paradigm of science, is nevertheless misleading - and that difference between social and physical science is something for which we may (and perhaps should) be grateful.

\section{The role of the social sciences in human life}

What is the paradigm of the social sciences? What stands to them as physics stands to the physical sciences? Which of them could claim to define the ontology of all of the social sciences, and provide the key to their success? As we can readily observe, the social sciences are more problematic than the physical sciences even when it comes to their definition: none can claim to be the paradigm of the social sciences as a whole. In Kuhn's terminology (Kuhn 1962), the social sciences are in their pre-paradigmatic stage, where none has achieved dominance over the others to such an extent that it defines the social domain in the way physics defines the physical domain. In pre-paradigmatic science, Kuhn claimed, “...though the field's practitioners were scientists, the net result of their activity was something less than science" (Kuhn 1962, p.13). As fecund as this historical observation of Kuhn's has been, I will argue the contrary view that the social sciences are more than science, not less.

True, the individual social sciences are more diverse, more independent from one another than the physical sciences. Psychology, political science, economics, anthropology, sociology, etc., remain sciences in the plural, and resist unification under a particular, paradigm-dominant, social science. They are competing programs to explain human behavior. There is no hierarchy in the social sciences (unlike the physical sciences). None has achieved anything like the powers of explanation, prediction, and control achieved in physics - and it is just such power that made physical science monolithic, and permitted it to extend the rule of the "fundamental forces and/or particles" over the entire physical domain.

in university calendars and other academic contexts) - as though Homo sapiens, the paradigm of the social sciences, were not natural. This is an intellectual hangover from the days of Galileo and Descartes, who secured a place within human cognition for the physical sciences by declaring the soul outside the reach of physics, and safely within the domain of religion and the Church. But nowadays it is plain that human beings are naturally occurring animals, visible to the naked eye, with a location in space and time, composed largely of complex hydrocarbons that grow or decay depending on their physical circumstances according to well known physical laws. The social sciences are therefore within the natural sciences, properly understood. The proper logical complement to the social sciences is not natural science, but physical science. 
The psychologist would perhaps be best placed to claim the ability to predict Smith's fateor, to put it more scientifically, to estimate the relative probabilities of outcomes 1 and 2 . But even then, the psychologist would require more knowledge of Smith, including perhaps some behavioral tests, analysis of bodily fluids to tests for drugs or the presence of metabolite residues indicative of stress or neural disorders, etc. And, of course, if our mythical Smith were to be observed and have these tests administered, it would change his future behavior with far ranging consequences including perhaps that neither outcome ${ }_{1}$ nor outcome $e_{2}$ occurs.

If we were in a Socratic mood, we might annoyingly ask the psychologist: Would you, at least, be able to predict outcome 1 or 2 with, say, a two-thirds accuracy rate, even if you were to be magically presented with all of the data you could wish in order to apply the theory with which you would do your predicting? Would you wager your research grant money on it at odds of double-or-nothing (if you bet 1 dollar and you are right you get 2 dollars back, if you are wrong you get nothing), thereby guaranteeing infinite research money so long as you can predict the outcome better than a coin toss?

To this the psychologist is apt to reply along the following lines: the precise prediction of behavior is not the objective of psychology in the first place. Sure, it would be nice to have such a deep understanding of human nature, but psychology has a therapeutic goal as well as a purely epistemic goal. Indeed, the social scientist may (but also may not) go even further, and state that the epistemic goal is pursued merely as a means to the therapeutic goal. Generally speaking, social scientists seek - and quite reasonably claim-practical wisdom as well as scientific insight. In Aristotle's terms, that means psychology is not mere theoria, but a branch of philosophy itself. Therapy presupposes a sufficiently healthy concept of human wellbeing, or happiness, and that concept cannot be defined within the context of any one aspect of human existence such as politics, society, the body, or the mind. Human wellbeing can only be defined from the global viewpoint of philosophy.

And quite remarkably, from the philosophical point of view, therapy (and its implicit concept of human well-being) is something the social science, psychology, shares with the physical science, biology. Biology is unique among the physical sciences for having its own therapeutic and clinical practice in the form of its inclusion of medicine as part of its overall scientific undertaking. Psychology and Biology are sciences that we collectively apply to ourselves via the discipline of medicine. For the human animal, like other animals, suffers, from many things - and we seek salvation through treatment: therapy. These facts are woven into the fabric of our lives. You can get a day off because you, your heart-or your mood - is unwell. Depression, a medical disease which is treatable through drug or behavioral therapies, will get you this day off just as surely as a broken leg. Psychiatric and psychological practitioners will be paid by the state to treat you, and on the weight of their signature you will be excused for being absent from your work or your class. Biological medicine treats diseases of your body, and psychological medicine treats diseases of your mind.

Not only that, but doctors and psychiatrists (as doctors of the mind are called) can provide expert testimony at your trial (thus placing them in a distinct sociological class from the other social scientists, anthropologists, political scientists, economists, sociologists, etc., who seldom are asked to give expert testimony in court). 
To illustrate the significance of this point, let's return to our mythical Smith, who upon hearing the shocking news of his mother's death, was treated by Dr. Holman, the troop physician, for shock. Smith's pulse, temperature, and blood pressure were off the chart. (These physical indicators are still used today, only we now call shock "acute stress reaction".) When released back into his unit, Smith's symptoms recurred. It soon became apparent that Smith was of little value as a military asset, so he was placed under the care of Holman, who, as it happened, was a Major in the Royal Canadian Air Force, a career officer who had served in the First World War, on his way to command a military hospital specializing in what was then called shell-shock (and which we now call "post-traumatic stress disorder").

After a few weeks of therapy and observation in Holman's hospital in England, Smith's condition improved, and Holman began releasing him on day-passes, and then eventually weekend passes as Smith proved he would return to the hospital as ordered. Smith could leave the hospital, but he couldn't leave the air force. He was under Holman's command, and like a good soldier, he obeyed. Smith seemed on the path of a normal recovery, and managed small jobs at the hospital, pleasing Holman and reassuring him in his treatment. So Holman was shocked (if not precisely in the medical sense) in May of 1941, when Smith was brought back from his week-end leave trembling and in handcuffs, arrested by Military Intelligence on suspicion of treason: spying for the enemy! Naturally, Holman couldn't help wonder whether he had made a mistake in releasing Smith in the first place. Should he have?

\section{The unity of the social sciences in the disunity of the human being}

As we have seen, physical science is united under the ontological umbrella of physics. Is there any corresponding sort of unity in the social sciences? Yes, but the parallel involves a striking and philosophically important dis-analogy between the physical and the social sciences. Whereas the physical sciences are unified by the most elementary phenomena of the known universe, the fundamental particles and forces, the social sciences are unified by the most complex phenomenon of the known universe: the human being.

To the extent there is any unity of the social sciences, it is found in the paradigmatic role of the human being in each. (Surely it is no accident that the French term for the social sciences is the sciences humaine - it correctly identifies their essential subject.) The human being is the paradigm political being, paradigm psychological being, paradigm economic being, and (obviously!) paradigm anthropological being. From the point of view of empirical knowledge, this is quite reasonable. We human beings stick out like a sore thumb among the life-forms of the planet. Only we drive automobiles, cruise the internet, eat pizzas from the corner shop, are aware of our flawed nature, and try to do something about it. Some scientists even go so far as to see us as living outside the ecosystem (Eldredge 2001), ${ }^{2}$ a

\footnotetext{
${ }^{2}$ Eldredge says, "Humans do not live with nature but outside it. Homo sapiens became the first species to stop living inside local ecosystems. All other species, including our ancestral hominid ancestors, all preagricultural humans, and remnant hunter-gatherer societies still extant exist as semi-isolated populations playing specific roles (i.e., have "niches") in local ecosystems. This is not so with postagricultural revolution humans, who in effect have stepped outside local ecosystems. Indeed, to develop agriculture is essentially to declare war on ecosystems."
} 
planetary disease (Suzuki 1994)33, an invader upon the very bosom of Mother Earth who gave birth to us in the first place-a bizarre paradox!

And yet it is understandable that, however it is conceived, the manifest gulf between us and the other life-forms of the planet will express itself somehow even in science-just as it is understandable that we often look upon that gulf with pangs of guilt. For we are the ones who brought this world and its life-forms to the brink of nuclear winter - a catastrophe for which scientists themselves feel a particular species of guilt. So, the more things change, the more we end up with the same thing: scientists now thunder about our guilt where not so long ago this was the function of priests. Now we measure our guilt by the degree of our environmental impact, though it seems just like yesterday we measured our guilt by the degree our perverse hearts turned away from God's commands.

And so neither the unity of the social sciences, nor of science as a whole, nor the very unity of the universe itself, can heal the divisions within the human being. That in itself is no criticism of science, for religion fails in precisely the same way. From the outside we are from the scientific point of view unpredictable, and from the religious point of view freebut from the inside we feel neither truly free nor truly forced in what we say, do, or think. Instead we are aware of the tensions inside of ourselves, our self-knowledge being often outflanked by our self-surprise. And so we sometimes do what we conceive as wrong, we feel guilt, and our moral authorities, now expanded beyond religion to include science, thunder our accusation, prophesy doom, and tell us how to regain our innocence. Surely it is no accident that environmental science's ideal of sustainable human life bears more than a passing resemblance to the Garden of Eden (Foss 2008, Ch. 7).

So science, the self-proclaimed guardian of objective truth, that sticks to the facts and nothing but the facts, nevertheless chastens and upbraids us. Again a paradox: for we have come to accept the scientific view of our nature, which says that everything we do was caused. Our science and technology are products of evolution just like our feet and brains. But if I am caused to do what I do, I cannot feel real guilt about it. I confess that if I very seriously and honestly imagine that the wicked things I do are completely and utterly caused, I cannot feel any real guilt. If, as the Stoics suggest (Konstan 2008, Ch. 2), I conceive there is no punishment, no suffering, no loss of happiness for myself or anyone else whatsoever over my actions (for this, too, pains me), then guilt in the old religious sensethat feeling of failure, inadequacy, of shrinking to the size of a mouse, and the imminence of deserved pain - cannot be felt.

A mere 50 years ago the common view of the many was that the human being is composed of two elements: body and soul. In this ancient view, which is still pervasive, our souls are thought to be indispensible to our very essence, for they are the part of us which permits us to be conscious: our souls are the divine machinery of our existence as conscious beings. To be is to be conscious - as Descartes said: when we are in a dreamless sleep, or what we would now call a coma, we cease to exist. Our essence is consciousness. ${ }^{4}$ Ah yes, but the religious

\footnotetext{
3 Suzuki says, "... the monster is us. ...We are overrunning the planet like an out-of-control malignancy," and goes on to speak about "the war to save this planet."

4 I argue at length in Science and the Riddle of Consciousness: A Solution (Foss 2000), that consciousness can be studied scientifically. It is noteworthy in this context that such scientific study requires communication between the investigating scientist and the human subject whose consciousness is being investigated.
} 
doctrines (more or less) accepted by both our mythical spy, Smith, and his military doctor, Holman, (more or less) assured them that if they were ever in a coma and died, they would awaken on the threshold of heaven to be judged. As the great theist philosophers taught, in their new awakening Smith and Holman would be awake as never before, their eyes wide with the heavenly marvels before them: and the interior eyes of their minds wide with every event of their entire lives present before it-and its moral import.

This view taught that ultimately all human beings went to their just reward because of their own conscious choices. Unconscious choices, on the other hand, were excusable in the eyes of God-or so Holman believed in May of 1941, when he received orders from Military Intelligence to hand Smith over to them for interrogation and trial by military tribunal. Holman thought in his own mind (and, so to speak, soul), on the basis of hours of communicating with Smith, that Smith was -in all likelihood-suffering from a psychiatric disorder, and hence should be kept in medical care, not delivered to the tribunal, where he might just be bullied into a confession and then hanged.

Should Holman turn Smith over to Military Intelligence, as commanded-or should he countermand MI and keep Smith under his care (with his leaves, presumably, cancelled)? What would happen under either course of events weighed heavily on his mind. Can the psychiatrist of our day, or any other sort of officially authorized professional psychologist, tell Holman what would happen? Can she/he tell us the likely outcome as concerns any major ethical or legal category like Smith's likeliness to do good or evil, to abide by law or become a criminal, aut cetera?

As self-proclaimed scientists, social scientists grant that human beings are precisely the biological species Homo sapiens, thereby granting the universal ontological dominion of physics. But even if they (and we) grant the universal rule of physics-even over the human being itself - they nevertheless are not forced (and we are not forced) to "reduce" the human being to physics. And while this fact may-or may not-impress a majority of professional psychologists, it is crucial as far as the professionally sanctioned actions of the social scientist are concerned, for human beings must be treated with respect, even if that respect is not commanded by God (but see Rollins 2006 for the many transgressions of this rule). This is, as it were, partly a legal reality for most practitioners who will read these words: the psychologist cannot harm people in either their therapeutic or in their research practice. But it should also be a social, political, and moral reality as well.

\section{The constant advance of science into human nature and life}

And yet we are gradually being reduced to physics, nevertheless - even if this reduction can never be complete. This is most obvious when it comes to our bodies: the heart, after all, is a mere pump, and can be replaced. Of course our replacements are always crude and in many ways inferior to the healthy organ itself - but the main point remains. Lamettrie (1748) must be granted his point when it comes to the muscles and bones, the heart and lungs. But our minds are being reduced to physics, too, though the reduction is less dramatic. We now know, for example, that the murder of 16 people by a Charles Whitman, who killed them in

My account is not unique in the respect (see, e.g., Dennett 2003). Given that this is so, what I call personal knowledge will be an essential part of the social sciences - as will emerge towards the end of this essay. 
shooting rampage at the University of Texas in 1966, was caused by a tumor in his brain. He kept a diary detailing his gradual conquest, despite his struggles, by a compulsion to kill. So these were not murders, (criminal acts), but killings (deaths by the hands of one criminally insane). Nor would I (or you, probably) hasten to call them immoral acts either, for the killer was obviously a victim of moral luck in Thomas Nagel's sense (Nagel 1979): he was no worse than you or me-until he got his tumor. Long before his fateful deeds, he reported a growing compulsion towards killing, a compulsion of which he was ashamed and for which he sought treatment.

David Eagleman says "criminals should always be treated as incapable of having acted otherwise" (Eagleman 2011, p. 177)-hence with respect, even if we feel we must take measures to quarantine them for reasons of public safety. Such quarantined (not imprisoned) victims of socially unacceptable diseases (who in the 1960s were treated as "criminally insane" - a phrase which now sounds oxymoronic) are to be treated like other patients insofar as their behavior permits: friends and family can visit, and even bring a cake or a television set as a gift. Just because one's (psychological or social) disease causes harm or death does not mean one should be chained or mistreated. We agree that carriers of harmful or even deadly diseases must be accorded the same human rights as you or me: Why would victims of brain diseases be any different that victims of diseases in other organs of the body? So Lamettrie must be granted his due even when it comes to our minds. A social scientist who does not accept that the mind is the brain must, after all, reject modern biology and modern medicine, and to that extent does not accept that a person is made of atoms and so must reject physical science as well. So such a person would have little claimand even less motive - to be a scientist.

But when we, for example, permanently quarantine a pathological killer, are we to think of him or her as a machine? No. Not an ordinary machine, anyway, for ordinary machines do not have rights. How then? That is a matter of debate. Rorty (1989) argues that all humans who speak deserve being listened to sympathetically, like R. D. Laing (1971) who professed we should listen sympathetically even to the insane, and countless others before and after. As we are all informavores, we cannot claim to understand each other unless we access the information we communicate to each other-unless, that is, our knowledge is personal knowledge. 5

But how are we to sympathize? Can we truly put ourselves "in the shoes", as they say, of the pathological killer? Can we imagine ourselves freely choosing what to eat and where to go but nevertheless unable to prevent ourselves from killing other human beings? If, as seems likely, human beings are quite diverse, then we will have difficulty sympathizingfeeling the same way as - those people we are used to describing as bad, evil, criminal, or perverse, like the pathological killer. If not sympathy, then what motivates us to advance the rights of the pathological criminal? Is there another basis for human respect?

Some social scientists still employ the ancient link between freedom and dignity (so convincingly critiqued by B. F. Skinner in Beyond Freedom and Dignity, 1974). As Stephen Pinker says, even though our actions finally are caused by factors outside of our control, we

\footnotetext{
${ }^{5}$ As noted before, personal knowledge is a theme in this essay to which we will return towards its conclusion.
} 
approximate free beings (Pinker 1999, p. 56). It is, I suggest, only because of this approximation -in particular our unpredictability - that even scientists like Holman and soldiers like Smith were able to believe in the existence of their souls and the freedom it bestowed. Some still believe the human soul exists, as is their right under both our laws and customs. Even scientists, I suggest, can still harbor such a belief, braced by the scientific fact of our unpredictability, as argued by William James (1884), who redeveloped Pascal's argument for letting the heart lead the head for a more scientific age. If, even under ideal conditions, we could precisely predict the behavior of one person making morally relevant decisions, second by second, with anything like the precision we predict the trajectory of a thrown stone, then we could justifiably surrender our own freedom-and-responsibility (for the two come as a married couple). Only then would the evidence speak clearly against our freedom, only then would human beings be "reduced to physics" (Foss 1987). Only then could I find it in my heart to forgive myself for something for which I truly felt guilty.

Our shame, our guilt, can be a precious thing, and not to be sacrificed at the first thunderings of causal determinism. It is a pain, a shrinkage of oneself in one's own eyes, a sickness and trembling that comes with the taste of ashes and death - and yet that bears the amazing power of rebirth: Real guilt, the guilt $I$ feel for my own wickedness, that which makes me look down in disgust upon myself as if from on high, that guilt carries the shock required to change one's self.

We are the only animals who blush-or need to, as Mark Twain observed. We are such intensely social animals that we are wired up to reveal our own guilt with a flash of red in our very face so that our transgressions can be spotted by our loved ones and neighbors (Ridley 1996, p. 139). We all wear our hearts on our sleeves, smiling, frowning, laughing, crying - and flashing red to reveal not only bad things we have done (shame) but bad things we bear indirect responsibility for (embarrassment), things such as rude behavior of our compatriots. ${ }^{6}$ But this too, as a biologically determined item of one's own nature-and let's be clear from the start that not everyone (in particular not the psychologically pathological) blushes at the same things - is a trap from which we may wish to escape: thus reaffirming our freedom to will what we want, despite our inborn nature. We have turned evitability, to coin Dennett's perceptive wordage (2003), into a high art. Some of us have not only learned to suppress the race of hot red blood to our face, but even the racing of the shamed heart hidden in our chest.

And yet we cannot deny the advance of social science in explaining human behavior. We face what Dennett has so aptly tagged as the "Specter of Creeping Exculpation" (2003): as the credibility of the neural mechanisms driving us advances, the concept of responsibility must correspondingly retreat. The retreat of responsibility does not mean, however, that we must retreat in the face of human violence. If the pathological killer cannot be relied upon to police her/himself, as it were, then we cannot permit her/him freedom in the moral, social, political, and legal sense. Even the most aggrieved parent of the most innocent victim of such a killer has no right to vengeance against the killer-but only because the act was unfree-unowned by any fully capable person. The pathological killer has lost the moral credentials to own her/his killings - the freedom and responsibility - a credential that is

${ }^{6}$ The similarities and distinctions between shame and embarrassment are clearly drawn by Bedford (1964). 
required to walk freely among us. But it does not follow that she/he has forfeited her/his respect as a human being.

But we do not accord respect to mere mechanisms! If there is a pathological mechanism inside the killer, then should we cut it out? Should we remove it - if only we can-through treatment, therapy, drugs, surgery, whatever? We would do that with a cancer, why not with a cancer of the very essence of human dignity: freedom (and its logical spouse, responsibility)? Well, again, as Rorty says (1989), even the most "irrational" among us deserves to be heard - even if we struggle to comprehend. ${ }^{7}$ For we are informavores. Not only our blushes, but also our words bear information, are species of the eidos that flow among us - and not only us, but amongst all living things. For DNA, too, is pure structure. Each individual strand of the DNA in our body (where "our" now signifies all living things) must go the way of all flesh, and decay. But its form-its structure, will go on in our kin, the torch of life in their bodies (whether single-celled or trillion-celled, whether plant or animal, whether healthy or pathological).

Which brings us back to the point: our exculpated killer may refuse our treatment, our psychotherapy, our surgery, no matter how pathological her/his desire to kill may be-and no matter how personally hellish it may seem to her/him when viewed through the aspect of her/his own guilt, shame, or embarrassment. Even if the desire to kill is felt with lust and rejoicing, the pathological killer has the right to deny treatment, just as she/he would for a cancer. We have no respect for her/his disease, but for her/him. This is not to say that we must go to any length to protect and nourish her/him: If faced with saving either our own children or her/him from fire, we might justifiably save our children. On the other hand, we do not simply kill or chain her/him either.

Let's not try to argue this here, let's instead return to the certainties of our mythological Smith - who, as it turns out, has also committed a crime, a crime at least as grave as murder. Holman, his military doctor, had interviewed Smith at length in his psychoanalysis, and knows beyond a shadow of a doubt that Smith aided, abetted, and protected $\mathrm{Z}$, the seductive Nazi spy he had been seeing on his week-end leaves. In fact, Smith helped her to escape arrest, which was treason, a hanging offence in wartime (the legal and moral equivalent of murder of one's fellow citizens). But Holman knows that a crime is a crime only if the act is free. Smith knew what he was doing, understood the consequences of his actions, and knew they were wrong-but his actions were not under his voluntary control. On the basis of his analysis of Smith, Holman believed - or thought it likely - that Z was a dominant personality who controlled the psychologically wounded Smith in a pathological sexual relationship. (Though Holman would have laughed at the idea that he accepted Adler's psychoanalytic theory, like many other medical men of his day, he had nevertheless absorbed some Adlerian concepts in his schooling as a mere restatement of common sense.)

\footnotetext{
${ }^{7}$ Rorty suggest that the ancient epithet of "irrationality" is always used whenever someone insists on disagreeing with us despite listening to our arguments - but that it carries no logical weight. While I recommend Rorty's arguments for your consideration, I would also remind us all that the concept of rationality began with Pythagoras, who thought that all reality was composed of numbers, and all relations between things were expressible as whole number ratios - a charming antiquity of thought, but completely insupportable given what we now know.
} 
So Holman refused to release Smith. Did he do the right thing? Holman was quite sure he had. Smith must be afforded the presumption of innocence, and given that presumption, along with Smith's inferiority complex (as Holman conceived of it), there was no proof of any crime on Smith's part. And yet, Holman still had his doubts. Spying was serious business in wartime, when innocent lives were at stake. But in the end he simply couldn't overcome his own ignorance, and no amount of reflection and worry could overcome his sheer lack of understanding. People were such mysteries. He had listened to Smith's account of what he had done so often and so well that he felt he really did understand him - and yet he couldn't be absolutely sure what he might do, or what he was capable of doing. But, as we now understand more thoroughly: No one can.

Mysteries humble the scientist, and Holman's humility made him incapable of tossing this man he had come to know into the efficiencies of military justice.

\section{Social science is more than mere science}

And so, let us return to our question: are the social sciences really sciences? The answer, I propose, is yes. The social sciences are empirical sciences in the most pure and simple sense: they aim at understanding Homo sapiens by empirical study and the development of laws, representations, maps, predictive models, etc., of human phenomena that are judged by the precision of the model, the accuracy of its correspondence with observation, and its completeness relative to the questions posed. ${ }^{8}$ Like many physical sciences, such as meteorology, turbulence studies, geology, river hydrology, quantum mechanics, and so on, the social sciences are barred from ever becoming perfectly precise. Only simple systems can be predicted with infinite precision-whether in physical science or social science. The elements behave in elementary ways, but complex structures behave in ways that outstrip our ability to handle the variables or make the complex calculations tracking their interactions. This is true for the weather, for rivers, and for human beings.

Never lose sight of this fact: Only we care where the boundary is drawn between social science and the other sciences. We are unique in this regard - and in so many others. For one thing, it is quite plausible that we are in fact the most complex phenomenon we have yet found in the universe. For another, there is no guarantee-indeed no good reason-to believe that our intelligence is capable of understanding itself. Intelligence may always be more complex than it is smart. In any case, we observe deeply rooted physical constraints on our own self-knowledge. To the Socratic maxim, "Know Thyself!" science has after many centuries replied "Impossible!"

To this, Socrates has already stated his counter-reply: If I am wiser than other men it is because I know that I am not wise. The world remains a mystery, and we remain mysteries, so Socratic wisdom remains wisdom.

So, yes, the social sciences are truly sciences, even though their subject matter is mysterious - in that they are not alone. But social science is also integrated into our systems of education, medicine, justice, politics, economics, etc. - and this gives it great power, hence

\footnotetext{
8 I discuss and defend a view of science as modeling of nature aiming for precision (of what the model says), accuracy (agreement of what it says with observation and measurement), and completeness (including what we want to know or understand) in Foss (2000) ch. 2; and Foss (2008), ch. 6.
} 
great responsibility. Power must be exercised with humility, in the face of the mystery of being human. For this mystery, though proven by physical science, is not even expressible in the language of physics or chemistry. Physical science examines the things of this world in terms of their physical parameters, but meaning, the collection, transformation, storage, communication, etc., of information, is not captured in physical parameters. The physical parameters of the words "Second world war" on this page do not causally connect them to the trillions of events of which that sorry human conflagration was comprised. It is instead your understanding of them that permits you to think of that war, which no longer exists, lost on a point in time and space now perfectly inaccessible to anything other than thoughtthrough its meaning.

So social science is really and truly science-but not just science: it is more than science for it also includes-and must include-the phenomenon of information, and hence meaning. This takes it beyond the boundaries of science as understood in the physical sciences. In addition to this special feature of social science, which concerns mainly its epistemology, metaphysics, logic, and method, the de facto social role of the social sciences gives it a special ethical feature as well: a responsibility for how we treat each other in our thoughts and institutions, particularly in education, medicine, law, and politics.

The ethical impact and responsibility of the social sciences is drawn out in our myth of Smith, for meaning is the essence of the myth. It was not the physical parameters of the sound of the words "Your mother is dead" that struck him down-it was their meaning. And it was the meaning of Smith's words, produced in response to Holman's analysis that enabled Holman to understand Smith, not as an object but as a human being-whether a fellow or not. ${ }^{9}$ Let us call this form of knowledge personal knowledge. It was in their mutual search for meaning and their partial success in discovering it and expressing it that Smith and Holman came to know each other - and such personal knowledge convinced Holman he mustn't turn Smith over to Military Intelligence.

\section{Seven morals for social scientists in the field, laboratory, or clinic}

Let me hasten to my morals - even before coming to my conclusions, which in the nature of philosophical exercises of this sort, must cast light on the world so that each illuminates the morals drawn.

Seven morals 10 for social scientists

1. The social scientist is humbled by the human being. This humility is both objective (there are significant restrictions on the social scientific quest for knowledge) and subjective (the social scientist is imbedded in a culture that respects human beings ethically and legally).

9 "Fellow human being" has the sense in English of both one's fellows-or kinship/ethnic/tribal/friendship connections - qualified generically by human: thus that all humans are fellows.

${ }^{10} \mathrm{~A}$ moral is a form of moral guidance offered as a gift, rather than forced upon its intended recipient as proven (as the word of God, logical necessity, the laws of reason, rationally presupposed, in accord with scientific law or fact, consistent with reason, etc.). 
2. Human freedom is worthy of respect. One form of respect of Homo sapiens for Homo sapiens that we hold dear is that expressed and enforced in the enlargement or the restriction of human freedom of action (by which I mean your freedom to do such things as move about unobserved, have and care for children, accept patients; and your freedom from such things as arrest, imprisonment, punishment). ${ }^{11}$ Social scientists enjoy enlarged freedom of action and responsibility - while at the very same time those among us who suffer from ethical or social dysfunction have restricted or curtailed freedom of action and responsibility. ${ }^{12}$

3. All human beings should have some humility. Ignorance is a human imperfection, an essential aspect of our nature - an embarrassment that is the font of philosophy, which Socrates therefore loved to expose in all of its pathos and grandeur-and for which he paid with his life, for we so hate being embarrassed. We professors of this modern era are no exception. Do you, Dear Reader, profess to be wise-so wise as to restrict the freedom of action of your adult fellows? Of course you do! We all do. Social scientists not only acquiesce to the institutions or childcare on the one hand and imprisonment on the other, but contribute to standards under which these institutions operate through education, clinical practice, professional advising, and so on. Social scientists not only do but should influence the constant evolution of these institutions and standards in view of their increasing understanding of humankind. This influence should be exercised with humility.

4. Humility is the basis for respect. The essence of respect (as opposed to fear or ritual deference) for another is humility: the sense that one is not so great that the wishes and feelings of the other can be disregarded. Respect is the emotional heart of equality: the sense that the other is at least one's equal, if not one's better.

5. Humanity deserves respect. ${ }^{13}$ Because humility presupposes so very little, nonbelievers of all stripes must also respect Homo sapiens, for no knowledge of God or evolution, ecomonics or ethics, anthropology or sociology, neuroscience or pychology, psychiarty or law, is required. Ignorance alone commands humility. Human action, and the hells and heavens we produce for each other, entail the same respect for ourselves that we have for any other natural phenomenon, whether the wind, ice-ages, or cometary impact. ${ }^{14}$ Homo sapiens, we, you, and I, Dear Reader, are capable of both great good and great evil, both awesome beauty and gross ugliness.

6. The most important form of understanding of each other is personal knowledge. ${ }^{15}$ Personal knowledge, the knowledge we gain from communication with each other, is

\footnotetext{
${ }^{11}$ Freedom of action in this sense is the fundamental sense of freedom for the human being, the sense of freedom he shares with other animals (and even plants), which I identify as natural freedom (Foss, 2008, ch 7). ${ }^{12}$ John Rawls (1971) is famous for arguing that extra freedoms and responsibilities for some citizens are justifiable if they work to the advantage of the population as a whole.

${ }^{13}$ Kant's famous moral dictum (the categorical imperative) says, "Always treat humanity, whether in yourself or another, as an end in itself." This highest level of respect Kant also sees as linked to human freedom (although he conceives of freedom metaphysically, rather than pragmatically as I do here), Thus, Kant's doctrine is quite similar to what I profess here-although his metaphysical arguments presuppose far more than the Socratic arguments I supply here.

${ }_{14}$ Beauty and awe marks the domain of the naturally sacred (Foss 2008, ch. 7): life, consciousness, and caring.

${ }^{15}$ Michael Polanyi still provides the most important study of the role of the individual person in knowledge in his book, Personal Knowledge (1958). Although he mainly restricts his account to the
} 
based on a feature of informavores: transmission of information between individuals or groups. Social scientists may sometimes deny themselves this form of knowledge of their subjects to avoid bias in the pursuit of knowledge, but wisdom is the sole basis on which we may restrict (or enlarge) each other's freedom. Wisdom requires that we avail ourselves of the information available solely through communication among us before restricting (or enlarging) each other's freedoms. ${ }^{16}$

\section{Human life is enlightened by freedom, humility, respect, and personal knowledge. ${ }^{17}$}

\section{The pro-verbial bottom line}

So what finally happened? Did Smith eventually arrive at outcome ${ }_{1}$, becoming a Nazi spy, or outcome $_{2}$, becoming a British spy? Obviously, there is no way to say: This unpredictability is a defining feature of our myth. To decree how this story ends runs contrary to its deepest message for the social scientist: We human beings are mysteries, so we if we investigate ourselves scientifically, it must be done with humility, respect, and fellowship.

So in all humility, based solely on my own personal knowledge, including insofar as possible my personal knowledge of you, my colleagues amongst those social scientists of whatever sort who still recall that you are philosophers in pursuit of Socrates' quest, I will choose two of the infinitely many paths Smith might possibly take to our two outcomes, like two shiny stars in among the myriads in the heavens, for you to throw out or keep, contradict or transform, be disappointed by or pleased-as unpredictably as you will. Please, do with them as you will. And please accept my most humble invitation into my abode, philosophy, if you have an ending of your own that leads to one of the two outcomes-for playfully engaging in such conceptual exercise was one of the original Academic pursuits: Lest Socrates die in vain.

1. Holman acted on his decision to withhold Smith from Military Intelligence by refusing to sign his release, insisting on the primacy of his authority over his patient. In response, Military Intelligence overruled Holman's command at a higher level, and sent an armed guard to take Smith in defiance of Holman's authority. Eventually, Smith was convicted of treason and imprisoned for 15 years.

physical sciences, it is in accord with the account given here, which extends his insights to the social sciences, where the scientific subject is an informavore. Cheryl Misak (2000) extends the account of personal knowledge among human beings to include the constitution of the state itself-following Polanyi`s lead in Science, Faith, and Society (1946).

16 Among adults these restrictions range from quarantine to imprisonment. Quarantine presupposes respect, and thus involves no punishment, while imprisonment presupposes neither respect nor refraining from punishment. Among children, and given the assumption of respect for children, restriction on action range from manual care (dressing and feeding of

the infant, keeping toddlers in a playschool classroom, denying adolescents phone-or other-contact with a sexual suitor) through verbal care (education, control of skill sets, friendships, and ideas).

17 One of the most amazing examples of this enlightenment is given by Green and Bigelow (1998), who explain how during the Basque witch-hunts of 1609-14, Bishop Salazar came to the understanding that socalled witches were just ordinary human beings like himself, through person-to-person interviews with accused witches - though his conclusion was contradicted by the substantial science of that time which provided rich empirical evidence for witchcraft along with rich theoretical support. Such is the power of human communication: it can reveal truth even in the darkest depths of ignorance and superstition. 
2. Holman acted on his decision to withhold Smith from Military Intelligence by introducing himself to the officer from Military Intelligence who had come to get Smith, and inviting him, Major Turn, into his office for a drink. There he began to tell Turn about Smith, as one judge of the common soldier to another, and found him quite receptive. Major Turn was especially intrigued by Holman's suggestion that Smith was deeply patriotic, but so overpowered by his own feelings of inadequacy that he compensated by acting as though he didn't care. Turn asked to speak directly with Smith, Holman agreed, and Smith and Turn hit it off, as they say. One thing led to another, and eventually Smith had reestablished his contacts in Z's circle-only now as a double-agent for the British. Smith became a decorated war hero, and eventually retired to live with Turn.

\section{References}

Bedford, Errol (1964) "Emotions." In Donald F. Gustafson, ed., Essays in Philosophical Psychology, New York: Doubleday and Co. Inc., pp. 77-98.

Dennett, Daniel (1996) Kinds of Mind : Toward an Understanding of Consciousness, New York: Basic Books.

(2003a) Freedom Evolves, New York: Viking.

(2003b) "Who's On First? Heterophenomenology Explained," Journal of Consciousness Studies, Special Issue: Trusting the Subject? (Part 1), 10, No. 9-10, October 2003, pp. 19-30

Eagleman, David (2011) Incognito: The Secret Lives of the Brain, New York: Penguin.

Eldredge, Niles (2001) "The Sixth Extinction."

Internet: http://www.actionbioscience.org/newfrontiers/eldredge2.html

Foss, Jeffrey (1987) "Is the Mind-Body Problem Empirical?" Canadian Journal of Philosophy, vol. 17, no. 3, (September), pp. 505-532.

(1992) 'Introduction to the epistemology of the brain: indeterminacy, microspecificity, chaos, and openness", Topoi, vol. 11, pp. 45-57.

(2007) "Only Three Dimensions and the Mother of Invention", Behavioral and Brain Sciences, vol. 30, no. 4 (Aug, 2007), p. 370.

(2008) Beyond Environmentalism: A Philosophy of Nature, New York: Wiley.

(2011) "Just the Facts, and Only the Facts, about Human Rationality?" Behavioral and Brain Sciences, vol. 34, issue 5, pp254-255.

Green, Karen, and John Bigelow (1998) "Does Science Persecute Women? The Case of the 16 ${ }^{\text {th-17th }}$ Century Witch-Hunts," Philosophy, vol. 78, pp. 195-217.

James, Williams (1884) "The Dilemma of Determinism," republished in William James, The Will to Believe, 1897.

Konstan, David (2008) A Life Worthy of the Gods: The Materialist Psychology of Epicurus, Las Vegas, Athens, Zurich: Parmenides Publishing.

Kuhn, Thomas S. (1962) The Structure of Scientific Revolutions. Chicago: The University of Chicago Press.

La Mettrie, Julien Offray de (1748) L'homme machine.

Laing, Ronald David (1971) The Politics of the Family and Other Essays. London: Tavistock Publications.

Miller, George A. (1983) In Fritz Machlup and Una Mansfield, eds., The Study of Information: Interdisciplinary Messages, New York: John Wiley and Sons, p.111. 
Misak, Cheryl J. (2000) Truth, Politics, Morality: Pragmatism and Deliberation. Oxford: Routledge

Nagel, Thomas (1979) "Moral Luck", in his Mortal Questions. Cambridge: Cambridge University Press.

Pinker, Steven (1999) How the Mind Works. New York: Norton.

Polanyi, Michael (1946) Science, Faith, and Society. Oxford: Oxford University Press.

(1958) Personal Knowledge: Towards a Post-Critical Philosophy. Chicago: University of Chicago Press.

Ridley, Matt (1996) The Origins of Virtue: Human Instincts and the Evolution of Cooperation. New York: Penguin.

Rawls, John (1971) A Theory of Justice. Cambridge MA: Belknap Press of Harvard University Press.

Rollins, Bernard E. Science and Ethic. Cambridge: Cambridge University Press.

Rorty, Richard (1989) Contingency, Irony, and Solidarity. Cambridge, New York: Cambridge University Press.

Skinner, Burrhus Frederic (1948) WaldenTwo. New York: Macmillan.

Beyond Freedom and Dignity. New York: Knopf.

Suzuki, David (1994) Time to Change, Toronto: Stoddart Publishers. 
(C) 2012 The Author(s). Licensee IntechOpen. This is an open access article distributed under the terms of the Creative Commons Attribution 3.0 License, which permits unrestricted use, distribution, and reproduction in any medium, provided the original work is properly cited. 